\title{
Haematological changes in active chronic hepatitis with reference to the role of the spleen
}

\author{
P. J. TOGHILL AND SHEILA GREEN \\ From the General Hospital, Nottingham
}

SYNOPSIS The haematological role of the spleen has been investigated in a series of 22 patients $\stackrel{\infty}{\infty}^{\circ}$ with active chronic hepatitis. Severe pancytopenia occurred in one patient after three years of steroid $\stackrel{\infty}{\rightarrow}$ therapy and this episode was associated with an increase in spleen size and a high splenic index of $\infty$ red cell destruction. Although the spleen was usually enlarged in the remainder of treated and $\stackrel{\circ}{\supset}$ untreated patients no others showed increased splenic haemolysis. The red cell survival was slightly $\vec{c}$ reduced in most patients but splenic pooling of red cells and expansion of the plasma volume did not significantly reduce the haematocrit level. No consistent haematological differences were detected between the untreated and the treated patients.

Active chronic hepatitis is an immunological disorder in which frequently there is evidence of multisystem disease. Splenomegaly is a common association. Whilst serious haematological problems are unusual a hypersplenic syndrome may occur (Duesberg and Gramlich, 1967) and there have been reports of haemolytic anaemias (Pengelly and Jennings, 1971; Panush, Wilkinson, and Fagin, 1973). Recently interest in splenectomy in active chronic hepatitis has arisen following descriptions of its beneficial effects in the hypersplenic syndromes (Duesberg and Gramlich, 1967), as a method of enhancing immunosuppressive therapy (Boye, Nordöy, and Gjone, 1972), and as a primary therapeutic procedure (Fodor and Barbarino, 1972). We report here some aspects of splenic function in relation to blood changes in a series of patients before and after treatment.

\section{Patients and Methods}

A group of 22 patients were studied who formed a consecutive series admitted to hospital for investigation and treatment of active chronic hepatitis. Sixteen newly diagnosed and untreated patients were seen and studies were repeated on nine of these patients after three to 36 months on steroid therapy. The other six patients had already been on steroid or immunosuppressive therapy for between six and 28 months when first seen. The diagnosis of chronic aggressive hepatitis without cirrhosis was established

Received for publication 10 September 1974. on percutaneous or open liver biopsy in all cases using the criteria suggested by De Groote, Desmet, Gedigk, Korb, Popper, Poulsen, Scheuer, Schmid, Thaler, Uehlinger, and Wepler (1968). None of the patients were positive for hepatitis-associated $\AA$ antigen and none had Wilson's disease. No patients $\overrightarrow{\vec{P}}$ had been taking oxyphenisatin or alpha methyldopa.

The routine haematological investigations were $\bar{F}$ carried out using standard methods. Haematocrit levels were determined in duplicate with Wintrobe tubes, allowance being made for plasma trapping (Chaplin and Mollison, 1952). Erythrocytes were labelled with $80-100 \mu \mathrm{Ci}$ sodium chromate $\left(\mathrm{Na}_{2}{ }^{51} \mathrm{CrO}_{4}\right)$ and measurements of red cell mass and splenic red cell pool were made using the methods described earlier (Toghill and Green, 1972). The red cell survival was expressed as the time in days $D$ for $50 \%$ loss of ${ }^{51} \mathrm{Cr}$ from the circulating red cells $\left(\mathrm{T}_{50}{ }^{51} \mathrm{Cr}\right)$. With this technique normal values were $\mathrm{N}$ 24-28 days. The plasma volume (PV) was estimated using ${ }^{131}$ I-labelled human albumin, thyroid uptake $\stackrel{\circ}{N}$ having been blocked by the administration of oral $\omega$ iodine in the previous 72 hours.

Surface radioactivity was measured using a scintillation counter with a collimator of $3 \mathrm{~cm} \Phi$ diameter and $5 \mathrm{~cm}$ depth. Radioactivity was. recorded from the following sites with the counter vertical and the subject supine: $(a)$ heart, over the $\stackrel{\vec{D}}{\vec{D}}$ left sternal edge from third to fifth spaces; $(b)$ liver, $\stackrel{\odot}{9}$ in the right midclavicular line $4 \mathrm{~cm}$ above the costal $₫$ margin; (c) spleen, between the left midclavicular and axillary line over the seventh interspace.

The increases in organ/heart ratio during the period 

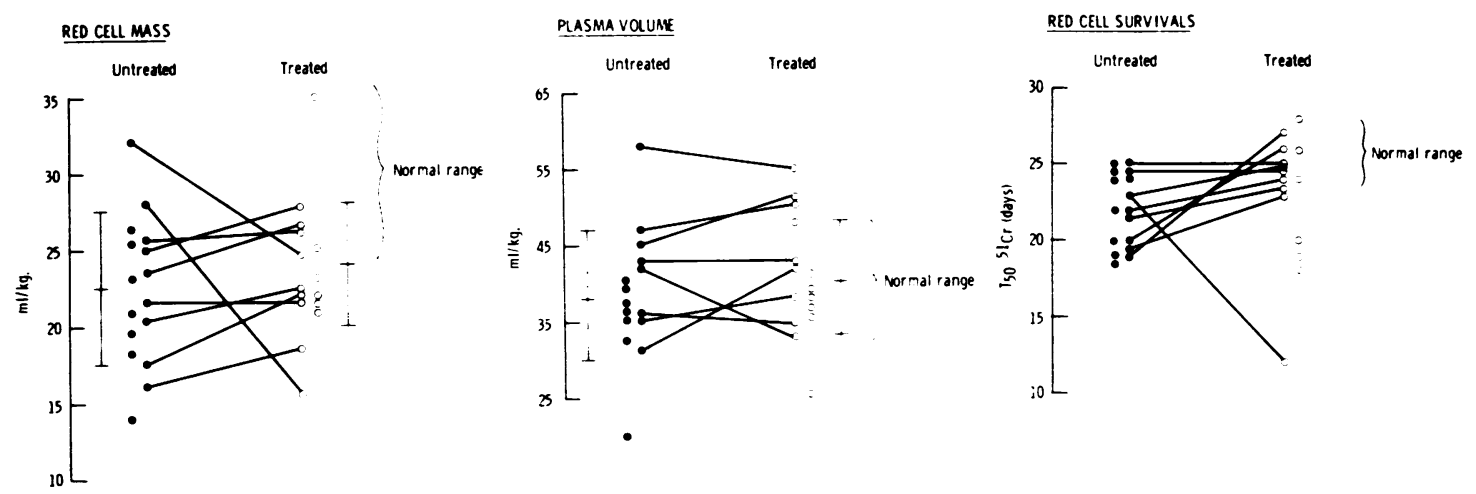

Fig 1 Red cell mass, plasma volume, and red cell survival of the patients with untreated and treated active chronic hepatitis.

of $50 \%$ loss of ${ }^{51} \mathrm{Cr}$ from the circulating red cells were determined. This change in ratio for liver and spleen when multiplied by 100 gave an arbitrary value for the liver and spleen indices as described by Jandl, Greenberg, Yonemoto, and Castle (1956).

Splenic size was assessed by ${ }^{99 \mathrm{~m}} \mathrm{Tc}$ scintiscanning. The spleen volume was calculated according to the formula $v=0 \cdot 3 \sqrt{ } a^{3}$ where $v$ represented the volume of the spleen in $\mathrm{ml}$ and a the largest spleen surface area in $\mathrm{cm}^{2}$ (Fischer, 1970).

\section{Results}

\section{HAEMATOLOGICAL FINDINGS}

Figure 1 shows the values for red cell mass, plasma volume, and red cell survival in the patients with active chronic hepatitis. The mean red cell mass in the untreated and treated patients was similar at $22.3 \pm 4.8$ and $24.1 \pm 3.9 \mathrm{ml} / \mathrm{kg}$ respectively. These values were significantly reduced below the normal values of $30.3 \pm 5.6 \mathrm{ml} / \mathrm{kg}$ for healthy adults $P<0.001)$. The plasma volumes in the majority of patients were normal with similar results in untreated (mean $38.5 \pm 8.6 \mathrm{ml} / \mathrm{kg}$ ) and treated patients (mean $40.3 \pm 8.0 \mathrm{ml} / \mathrm{kg}$ ). The red cell survivals $\left(\mathrm{T}_{50}{ }^{51} \mathrm{Cr}\right)$ of both the untreated patients and the treated patients are also shown in figure 1. In six of nine patients studied again after the institution of steroid therapy red cell survival was mildly prolonged, in two there was no change, and in the one patient in whom there was a hypersplenic crisis, the $\mathrm{T}_{50}{ }^{51} \mathrm{Cr}$ fell from 24 to 12 days. In this patient the Coombs test became positive but in all the other patients the test was negative.

Values for white cell counts and platelet counts are shown in figure 2. The total white blood count was substantially normal at first attendance in most of the untreated patients (mean $6.0 \times 10^{9} / 1$ ) and treatment with steroids did not significantly alter the levels (mean $6.4 \times 10^{9} / 1$ ). One patient had an eosinophilia of $12 \%$ of $3.1 \times 10^{9} / 1$ but in all the other patients the eosinophil count was less than $5 \%$. Seven of the 22 patients had platelet counts less than $150 \times 10^{9} / 1$ when first seen. Steroid therapy did not influence the platelet counts, the mean value in the

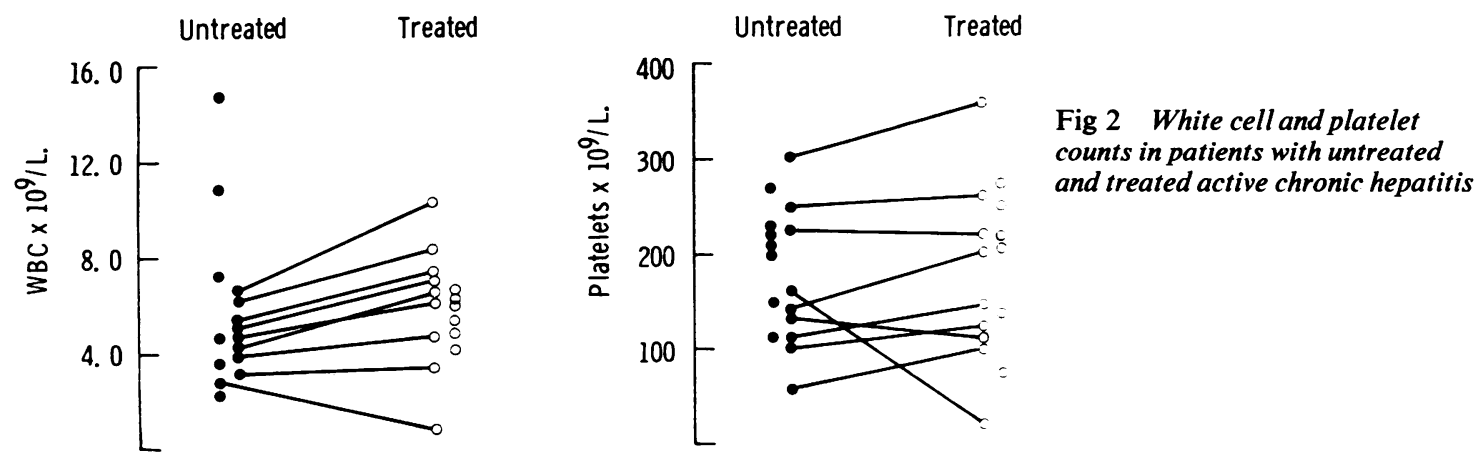

Fig 2 White cell and platelet counts in patients with untreated and treated active chronic hepatitis 


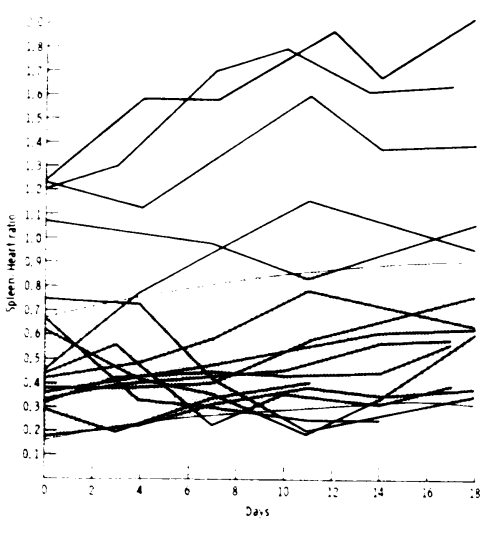

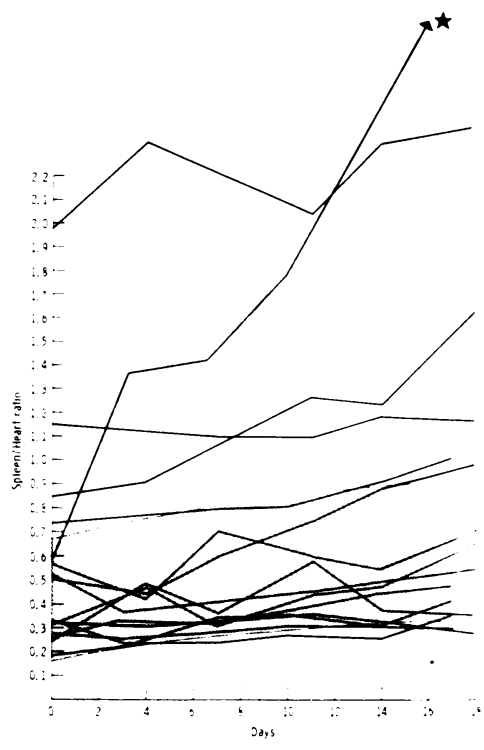

Fig 3 Results of surface counting studies showing spleen/ heart ratios in untreated patients (left) and in treated patients (right). Shaded area indicates normal range.

${ }^{*}$ Patient with hypersplenic crises untreated patients being $180 \times 10^{9} / 1$ and in the treated group $179 \times 10^{9} / 1$. LE cells were detected in four patients. Bone marrow biopsies were performed at first attendance. These were regarded as normal in all except two cases where there was an excess of lymphocytes forming 18 and $16 \%$ of the total cells.

\section{SPLENIC FUNCTION}

The splenic volume, calculated from the maximum surface area on the splenic scintiscan, was increased above the normal range of $0 \cdot 129 \pm 0 \cdot 043 / 1$ (Westin, Lanner, Larsson, and Weinfeld, 1972) in 15 of the 22 patients with a mean of $0 \cdot 250 \pm 0 \cdot 148 / 1$. Steroid therapy from three to 15 months produced a reduction in spleen size in seven of the nine untreated patients. A small splenic red cell pool of between 5 and $14 \%$ was detected in 11 patients. Owing to the technical difficulties inherent in this method of measuring the splenic red cell pool values of less than $5 \%$ were disregarded.

The results of the surface counting studies are shown in figure 3. The initial mean spleen/heart ratios in the untreated and treated groups were similar at $0.58 \pm 0.35$ and $0.63 \pm 0.49$ respectively. These findings did not differ significantly from the ratio of $0.56 \pm 0.18$ found in normal non-splenomegalic subjects. Some patients had high initial spleen/heart ratios of greater than unity but these patients did not show evidence of excessive accumulation of radioactivity in the spleen subsequently. The spleen indices of erythrocyte destruction were usually less than 40 as in normal subjects (Toghill, 1965). There was no consistent change in the splenic index with treatment. Marked splenic haemolysis only occurred in the patient with the hypersplenic crisis. In the 22 patients the splenic index bore no statistical relationship to spleen size, splenic red cell pool, red cell survival, or plasma volume.

\section{HYPERSPLENISM}

In this series of 22 patients there was no evidence of severe hypersplenism at first attendance. One patient suffered a relapse of hepatitis three years after starting treatment with steroids and during this phase she had severe pancytopenia. Her bone marrow, which was normal at the onset of hepatitis, showed at this stage marked hyperplasia of all three haemopoietic components while concurrently she had a haemoglobin of $7.0 \mathrm{~g} / \mathrm{dl}$ with a $28 \%$ reticulocytosis, a leucopenia of $0.65 \times 10^{9} / 1$, and a thrombocytopenia of $15 \times 10^{9} / 1$. The $\mathrm{T}_{50}{ }^{51} \mathrm{Cr}$ fell from 24 to 12 days and the splenic index was high at 148. The liver index was normal. The spleen volume rose only from 215 to $292 \mathrm{ml}$. The Coombs test was positive. LE cells were frequent. Leucocyte agglutinins were detected. Although splenectomy was contemplated a massive dose of steroids combined with azathioprine controlled the situation which did not recur, with a subsequent reduction in therapy.

\section{Discussion}

No attempt has been made in this present work to study any direct effect the spleen might have on the liver in a presumed autoimmune process. Instead an assessment has been made of the role of the spleen 
in relation to the haematological state in active chronic hepatitis. Theoretically enlargement and overactivity of the spleen might alter the formed elements of the blood in a number of ways. The syndrome of hypersplenism has been reported in $15 \%$ of patients with chronic hepatitis (Gramlich, Fischer, Dullien, and Lasotowitz, 1970). Occasionally frank haemolytic anaemia may develop (Read, Sherlock, and Harrison, 1963; Pengelly and Jennings, 1971; Panush et al, 1973). With gross enlargement of the spleen in chronic liver disease a large pool of erythrocytes may be sequestered in the spleen thus reducing the effective extrasplenic red cell volume (Donaldson, McArthur, MacPherson, and Richmond, 1970). Finally there is the possibility that the splenic enlargement per se might be associated with an expansion of the plasma volume to give a haemodilutional anaemia (Toghill and Green, 1972).

In this particular group of patientsserious haematological changes were unusual. Many patients had low haematocrit levels due to a primary reduction of the red cell mass with no haemodilutional component. Steroid therapy did not appear to influence the red cell mass. A frank haemolytic anaemia was seen in the patient who had what was presumably an autoimmune crisis in a severe but reversible exacerbation of disease. In other reports of Coombspositive haemolytic anaemias in active chronic hepatitis tagged red cell studies have not been carried out and the primary site of haemolysis has been uncertain. In our patient the total white cell count fell and leucocyte agglutinins were detected. Other workers have reported severe neutropenia in chronic active hepatitis and have been able to characterize a serum immunoglobulin $\mathbf{G}$ (IgG) antibody against neutrophils (Boxer, Yokoyama, and Wiebe, 1972). As yet there is little evidence available as to the role of the spleen in the thrombocytopenia of active liver disease, although it seems likely that platelet antibodies may occur in association with increased platelet pooling. The hypersplenic changes may usually be satisfactorily controlled by steroids, Boye et al (1972) have commented how well splenectomy may be tolerated in these critically ill patients.

Other non-specific effects of splenomegaly on the blood volume do not play an important part in chronic hepatitis. Although the splenic size is usually increased in chronic hepatitis this is never sufficiently great to accommodate a large splenic red cell pool which could, itself, lower the effective extrasplenic red cell mass. The findings in this study confirmed earlier work (Blendis, Toghill, and Williams, 1968) that the modest splenomegaly in liver disease is not usually associated with expansion of the plasma volume as occurs in patients with the gross splenomegaly of myelo- and lymphoproliferative disease.

We thank the Sheffield Regional Hospital Board for financial support for this study. We are grateful to Dr E. A. French for his reports on the bone marrow biopsies and to Dr Wagstaff of the Regional Blood Transfusion Centre for the red cell antibody studies.

\section{References}

Blendis, L. M., Toghill, P. J., and Williams, R. (1968). Effect of splenomegaly on the plasma volume. In Proceedings for the 3rd European Congress for the Study of the Liver. Moderna.

Boxer, L. A., Yokoyama, M., and Wiebe, R. A. (1972). Autoimmune neutropenia associated with chronic active hepatitis. Amer. $J$. Med., 52, 279-282.

Boye, N. P., Nordöy, A., and Gjone, E. (1972). Splenectomy in active chronic hepatitis. Scand. J. Gastroent., 7, 747-750.

Chaplin, H., Jr., and Mollison, P:L. (1952). Correction for plasma trapped in the red cell column of the hematocrit. Blood, 7, 1227-1238.

Donaldson, G. W. K., McArthur, M., MacPherson, A. I. S., and Richmond, J. (1970). Blood volume changes in splenomegaly. Brit. J. Haemat., 18, 45-55.

Duesberg, R., and Gramlich, F. (1967). Hepatopathie und Dysplenie. Hepatologica, 13, 1097-1104.

Fodor, O., and Barbarino, F. (1972). Splenectomia in Hepatita cronica. Med. interna (Buc.), 24, 259-266.

Fischer, J. (1970). Die Milzszintigraphie als Methode zur funkionellen Milzanlyse. In The Spleen, edited by Karl Lennert and Dieter Harms, pp. 11-23. Springer, Berlin.

Gramlich, F., Fischer, J., Dullien, K., and Lascotowitz, P. (1970). The spleen in liver diseases. In The Spleen, edited by Karl Lennerts and Dieter Harms, pp. 336-346. Springer, Berlin.

De Groote, J., Desmet, V. J., Gedigk, P., Korb, G., Popper, H., Poulsen, H., Scheuer, P. J., Schmid, M., Thaler, H., Uehlinger, E., and Wepler, W. (1968). A classification of chronic hepatitis. Lancet, 2, 626-628.

Jandl, J. H., Greenberg, M. S., Yonemoto, R. H., and Castle, W. B. (1956). The clinical determination of the sites of red cell sequestration in hemolytic anemias. J. clin. Invest., 35, 842-867.

Panush, R. S., Wilkinson, L. S., and Fagin, R. R. (1973). Chronic active hepatitis associated with eosinophilia and Coombs' positive hemolytic anemia. Gastroenterology, 64, 1015-1019.

Pengelly, C. D. R., and Jennings, R. C. (1971). Active chronic hepatitis and haemolytic anaemia associated with $\mathrm{Rh}$-specific antibodies. Postgrad. med. J., 47, 683-686.

Read, A. E., Sherlock, S., and Harrison, C. V. (1963). Active 'juvenile' cirrhosis considered as part of a systemic disease and the effect of corticosteroid therapy. Gut, 4, 378-393.

Toghill, P. J. (1965). Red cell pooling in the spleen. MD Thesis, University of London.

Toghill, P. J., and Green, S. (1972). The influence of spleen size on the distribution of red cells and plasma. J. clin. Path., 25, 570-573.

Westin, J., Lanner, L. O., Larsson, A., and Weinfeld, A. (1972). Spleen size in polycythemia: a clinical and scintigraphic study. Acta med. scand., 191, 263-271. 